\title{
UPTAKE OF OESTRADIOL BY RAT AND HAMSTER UTERI IN VITRO: EFFECTS OF ETHYNYL OESTRADIOL AND AN ANTI-OESTROGEN
}

\author{
K. W. PERRY AND E. R. FERGUSON* \\ Department of Endocrinology, Warner-Lambert Research Institute, \\ Morris Plains, New Fersey 07950, U.S.A.
}

(Received 20th August 1973)

Oestrogenic and anti-oestrogenic compounds that are effective antifertility agents for rats do not necessarily behave in a similar way for hamsters. The target tissues in the hamster are less sensitive to oestrogens and respond less to anti-oestrogens than those in the rat (Giannina, Butler, Popick \& Steinetz, 1971). These investigators suggest that differences in metabolism or oestrogen affinity may explain their observations. Experiments in vivo show that hamster uteri retain significantly less tritiated oestradiol than is retained by rat uteri under identical experimental conditions (Ciaccio \& Lisk, 1972). Prasad, Orsini \& Meyer (1960) have shown that, unlike the rat, oestrogen is not required for implantation in the hamster.

In the present investigation, the uptake in vitro of tritiated oestradiol and the

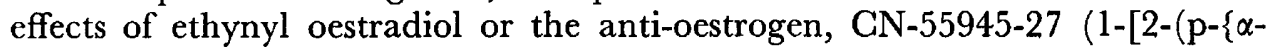
(p-methoxyphenyl)- $\beta$-nitrostyryl $\}$-phenoxy)ethyl] pyrrolidine monocitrate), on this uptake were compared in rat and hamster uterine tissue.

A tritiated oestrogen $\left(\left[6,7-{ }^{3} \mathrm{H}\right]\right.$ oestradiol $-17 \beta ; 40 \mathrm{Ci} / \mathrm{mmole}$; New England Nuclear Corp., Boston, Mass.) with radiochemical purity $\geqslant 96.8 \%$ and radioisotopic purity $>99 \%$ was used in these in-vitro studies. Benzene : ethanol $(9: 1)$ was used to dilute the tritiated oestradiol so that $0.16 \mathrm{ml}$ of the diluted isotope in $400 \mathrm{ml}$ incubation medium gave a final oestradiol concentration of $10^{-10} \mathbf{M}$.

The in-vitro system used for the uptake of tritiated oestradiol by uterine tissue was described by Jensen, De Sombre, Hurst, Kawashima \& Jungblut (1967). Uteri were obtained from immature (40 to $50 \mathrm{~g}$ ) Sprague-Dawley derived rats and outbred Lak : LVG golden hamsters. The slit uterine horns were stirred in beakers containing Krebs-Ringer-Henseleit glucose buffer ( $\mathrm{pH}$ 7.3 ) at $37^{\circ} \mathrm{C}$. Each beaker contained twenty uterine horns in $400 \mathrm{ml}$ buffer with $10^{-10} \mathrm{M}$-tritiated oestradiol. The effects of the oestrogen and anti-oestrogen on the uptake in vitro of the tritiated oestradiol were determined by adding unlabelled ethynyl oestradiol $\left(10^{-9} \mathrm{M}\right)$ or CN-55945-27 $(20 \mu \mathrm{g} / \mathrm{ml}$ or $3 \cdot 14 \times$ $\left.10^{-5} \mathrm{M}\right)$ to the incubation medium. Five uterine horns were removed from each beaker at the end of each specific time period, frozen in a dry ice-acetone bath

* Present address: Department of Physiology and Biophysics, University of Illinois, Urbana, Illinois, U.S.A. 
and freeze dried overnight. The dried uterine horns were weighed and then combusted for determination of $\mathrm{d} / \mathrm{min} / \mathrm{mg}$ dry weight.

The uptake in vitro of tritiated oestradiol by the hamster uterine tissue was significantly lower than that for the rat uterine tissue (Table 1). Tritiated oestradiol uptake by hamster uterine tissue (overall average) was $66 \%$ of that for rat uterine tissue. Ethynyl oestradiol and the anti-oestrogen (GN-55945-27) significantly inhibited the uterine uptake in vitro of oestradiol in a similar manner for both the rat and hamster. There appear to be no real differences in the trends of the effects produced by ethynyl oestradiol or the anti-oestrogen on the uptake of oestradiol by uterine tissue from the two species. The amounts of the uptake of tritiated oestradiol in the presence of ethynyl oestradiol were 41 and $44 \%$ of the controls for rat and hamster, respectively. In the presence of the anti-oestrogen, the amounts of the oestradiol uptake were 21 and $32 \%$ of the controls for the rat and hamster, respectively.

Table 1. The uptake of tritiated oestradiol by rat and hamster uterine tissue

\begin{tabular}{|c|c|c|c|c|}
\hline \multirow[b]{2}{*}{ Species } & \multirow[b]{2}{*}{$\begin{array}{l}\text { Incubation } \\
\text { time (min) }\end{array}$} & \multicolumn{3}{|c|}{ Geometric average d/min/mg tissue (dry weight)* } \\
\hline & & $\begin{array}{c}{\left[{ }^{3} \mathrm{H}\right] \text { Oestradiol }} \\
\left(10^{-10} \mathrm{M}\right) \\
(\text { control })\end{array}$ & $\begin{array}{c}{\left[{ }^{3} \mathrm{H}\right] \text { Oestradiol }} \\
\left(10^{-10} \mathrm{M}\right)+ \\
\text { ethynyl oestradiol } \\
\left(10^{-9} \mathrm{M}\right)\end{array}$ & $\begin{array}{c}{\left[{ }^{3} \mathrm{H}\right] \text { Oestradiol }} \\
\left(10^{-10} \mathbf{M}\right)+ \\
\text { CN-55945-27 } \\
(20 \mu \mathrm{g} / \mathrm{ml})\end{array}$ \\
\hline \multirow[t]{2}{*}{ Rat } & $\begin{array}{r}30 \\
60 \\
120 \\
180\end{array}$ & $\begin{array}{l}3500 \\
5592 \\
8400 \\
9374\end{array}$ & $\begin{array}{l}2121 \\
2708 \\
2955 \\
2505\end{array}$ & $\begin{array}{l}1153 \\
1246 \\
1334 \\
1575\end{array}$ \\
\hline & $* *$ & 6265 & 2554 & 1318 \\
\hline \multirow[t]{2}{*}{ Hamster } & $\begin{array}{r}30 \\
60 \\
120 \\
180\end{array}$ & $\begin{array}{l}2518 \\
4014 \\
5154 \\
5626\end{array}$ & $\begin{array}{l}1519 \\
1823 \\
2026 \\
1909\end{array}$ & $\begin{array}{l}1038 \\
1306 \\
1442 \\
1592\end{array}$ \\
\hline & $* *$ & 4137 & 1809 & 1328 \\
\hline
\end{tabular}

* Critical mean difference $=8.9 \%, P=0.05, \mathrm{n}_{1}=\mathrm{n}_{2}=10$.

** Overall average, critical mean difference $=4.3 \%, P=0.05, \mathrm{n}_{1}=\mathrm{n}_{2}=40$.

Analysis of variance of the radioactive data (logarithmic transformation) was carried out and is shown in Table 2. This analysis shows that highly significant differences existed between species, treatments, times and all of their interactions except for species versus time.

This in-vitro system provides a method for studying oestrogen-receptor interactions that excludes oestrogen biotransformation and metabolism that occurs in vivo in non-target tissues (Jensen, Numata, Smith, Suzuki, Brecher \& De Sombre, 1969). Thus, any differences observed in the present study can only result from uterine tissue metabolism, uterine membrane transport, oestrogen-receptor affinity and/or number of receptor sites or molecules available.

In this study, the uptake in vitro of oestradiol by the hamster uteri (overall average) was $66 \%$ of that observed for the rat uteri. The uptake in vivo of oestra- 
diol by hamster uteri was only 15 to $25 \%$ of that for the rat uteri (Ciaccio \& Lisk, 1972). A comparison of these data indicates that some in-vivo factor(s) and/or mechanism(s) reduce the uptake of oestradiol by the hamster uteri. Giannina et al. (1971) have shown that seventeen and twenty times more oestradiol is required by the hamster to give uterotrophic and contraceptive activities equivalent to those observed for the rat. Thus, it appears that the differences between the hamster's and the rat's requirements in vivo for oestradiol are not solely confined to the uterus and its ability to take up oestradiol as shown by the in-vitro data.

The data in the present study indicate that there are no real differences in the effects of ethynyl oestradiol and the anti-oestrogen, CN-55945-27, on the uptake in vitro of oestradiol by the uteri from the two species. Giannina et al. (1971) reported that the effects of oestradiol can be completely antagonized by

Table 2. Analysis of variance of the radioactive data

\begin{tabular}{l|c|c|c}
\hline & $d . f$. & $\log V$ & $F$ \\
\hline Species & 1 & $0 \cdot 71157$ & $396 \cdot 00^{*}$ \\
Treatment & 2 & 7.02964 & $3916 \cdot 00^{*}$ \\
Species $\times$ Treatment & 2 & $0 \cdot 19326$ & $107 \cdot 00^{*}$ \\
Time & 3 & 0.55555 & $309 \cdot 00^{*}$ \\
Species $\times$ Time & 3 & $0 \cdot 00066$ & $0 \cdot 37$ \\
Treatment $\times$ Time & 6 & $0 \cdot 10607$ & $59 \cdot 00^{*}$ \\
Species $\times$ Treatment $\times$ Time & 6 & 0.00861 & $4 \cdot 80^{*}$ \\
Residual & 215 & $0 \cdot 00179$ & \\
& & \\
\hline \multicolumn{3}{|c|}{$* P<0.001}$.
\end{tabular}

$1.0 \mathrm{mg}$ of $\mathrm{CN}-55945-27 / \mathrm{kg}$ in the rat whereas more than $5.0 \mathrm{mg} / \mathrm{kg}$ is required for the hamster. Also, eighteen and 100 times more ethynyl oestradiol is required by the hamster to give uterotrophic and contraceptive activities equivalent to those observed for the rat. From the in-vitro data it appears that the differences in the in-vivo uterotrophic, anti-uterotrophic and contraceptive activities between the rat and hamster are not due solely to uterine metabolism or interactions with the uterine oestrogen receptors.

These data strongly indicate that the differences in the effects of oestrogens and anti-oestrogens in vivo on the uterotrophic, anti-uterotrophic and contraceptive activities between rats and hamsters may be due either to one or to a combination of the following: (a) non-target tissue metabolism, (b) action on target tissues other than the uterus, (c) uterine oestrogen receptor affinities and/or concentration, and possibly (d) assay sensitivities.

The authors gratefully thank Parke-Davis, Ann Arbor, Michigan for the gift of CN-55945-27 and Mr N. R. Stasilli for the statistical analyses. The source of ethynyl oestradiol was Schwarz/Mann, Orangeburg, New York.

\section{REFERENCES}

CiAccio, L. A. \& Lisk, R. D. (1972) Effect of hormone priming on retention of ${ }^{3} \mathrm{H}$-oestradiol by males and females. Nature, New Biology, 236, 82. 
Giannina, T., Butrer, M., Popick, F. \& Steinetz, B. (1971) Comparative effects of some steroidal and nonsteroidal antifertility agents in rats and hamsters. Contraception, 3, 347.

Jensen, E. V., De Sombre, E. R., Hurst, D. J., Kawashima, T. \& Jungblut, P. W. (1967) Estrogenreceptor interactions in target tissues. Archs Anat. microsc. Morph. exp. 56, 547.

Jensen, E. V., Numata, M., Smith, S., Suzuki, T., Bregher, P. I. \& De Sombre, E. R. (1969) Estrogen-receptor interaction in target tissues. Devl Biol. Suppl. 3, 151.

PRASAd, M. R. N., Orsini, M. W. \& MeYer, R. K. (1960) Nidation in progesterone-treated, estrogendeficient hamsters, Mesocricetus auratus (Waterhouse). Proc. Soc. exp. Biol. Med. 104, 48. 